\title{
CATTLE BREEDING GOALS AND PROGRAMMES IN SERBIA ${ }^{1}$
}

\author{
V. Bogdanović, Radica Đedović, P. Perišić, M. M. Petrović ${ }^{2}$
}

Content: It is neccessary to define clearly the cattle breeding goals which must be achieved and as well as the programmes for their realization in order for the cattle breeding, the most important field of the cattle industry, to be economically profitable. We can identify in Serbia two the most important groups of the cattle breeds which are different according to the numerous phenotypic and production traits. These are Holstein-Friesian breed and European black-white breed on one side, and Simmental breed and Domestic spotted cattle in the type of Simmental on the other side. Lately, Busa and Podolian breeds are again of great importance, but from the aspect of maintaining genetic biodiversity in the national programme of protection and preservation of animal genetic resources. This paper shows the basic principles of defining the breeding goals in the cattle industry, as well as the ways of defining the breeding programmes and selection criteria, creating the breeding scheme and structure, the choice of parent couples and defining the plan for mating, control of the productional abilities and economic analysis of the realized activities.

Key words: Cattle, breeding goals, breeding programmes, models, variablity of the traits, economic value of the characteristics.

\section{Introduction}

The cattle production represents the most important field of the livestock production, and indirectly one of the most important fields of the agricultural production in general. Having in mind the importance of the cattle production it is necessary to define clearly the breeding goals for cattle, as well as the programmes according which the set goals will be achieved. In Serbia, as in many European countries, the production of cow milk, and young beef i.e. beef meat is organized by breeding specialized milk breeds, as well as dual purpose breeds. The specialized beef breeds, which are widely spread in Europe, in Serbia have a minor significance.

In Serbia we can identify two important groups of cattle breeds which differ very much by the numerous phenotypic and production characteristics. These are Holstein-Friesian breed and European black and white cattle on one side and Simmental breed and domestic spotted cattle in the type of Simmental on the other side. Lately, Busa and Podolian breeds are again of great importance, but from the aspect of maintaining genetic biodiversity in the national programme of protection and preservation of animal genetic resources.

Since the mentioned breeds are very different, we can not avoid the need for defining the specific breeding goals for each of them. Every breeding goal can be considered from different aspects, as well as to defined at different levels. If there is a zootechnical and economic excuse for it, the breeding goal can be defined at the level of individual cattle farm when each breeder can define his own breeding goal. At this level of defining the differences appear depending on the fact if the breeder is dealing with the breeding or with commercial animals. The goal can also be defined at the level of the association of the breeders of one cattle breed or at the level of the national herd of one cattle breed.

No matter what is the level of defining or organizing we must clearly know what is necessary to achieve with the specific zootechnical-economical conditions, as well as the way for achieving it. The goal of this paper is to show the basic principles of defining the breeding goals and programmes in cattle breeding, with the emphasis on the characteristics which can be significant for the improvement of the cattle population, as well as for the improvement of the cattle industry in Serbia.

\footnotetext{
1 Review paper supported by the Ministry of Science and Environment Protection, Project no. TR6858 - Revijalni rad je finansiran od strane Ministarstva za nauku i zaštitu životne sredine Projektom broj: TR6858

2 Dr Vladan Bogdanović, docent; Dr Radica Đedović, docent; Mr Predrag Perišić, asisstant, Faculty of Agriculture, Belgrade - Zemun; Dr Milan M. Petrović, scientific counselor, Institute for Animal Husbandry, Belgrade - Zemun
} 


\section{The principles of defining the breeding goals and programmes in cattle production}

Theoretically, the breeding goal represents the directed genetic improvement of the certain characteristics realized in successive generations of animals which accomplish the desired production through the future, but expected economic, social and ecologic production conditions (Groen,2000). More over, the breeding goals and programmes for their realization are not only important for the cattle industry, but the defining of them can play a big role in defining the development plans for the overall agricultural production in one country.

Clear defining of the breeding goals, i.e. what is necessary to achieve is a first phase in defining the breeding programme not only in cattle production but in livestock production as well. Although, the breeding goals are defined and realized in very different zootechnical, economical and market conditions, from the aspect of breeders each goals must fulfill two basic conditions, and these are (1) maximum profit and specific production conditions with (2) the risk of realization which is in the acceptable limits of the business. Also, what is being imposed as a very important condition which must be fulfilled during defining the breeding goals is the sustainability of the cattle production from the aspect of preservation of the ecological balance of environment and the present biodiversity, as well as from the aspect of disarrangement of the etological characteristics of animals and their health status (Olesen et al 1999, 2000).

Considering the breeding goal, the breeding programme is defined, which will on the optimal way contribute to the realization of the set goals. The defining of the breeding programmes is a very sensitive phase of the whole process, because during it we must define the characteristics which directly or indirectly influence the realization of the set goal, as well as the relative importance of each of the characteristics included in the breeding programme. (Groen et al, 1997, Dekkers and Gibson, 1998).

The starting point in defining the breeding programme is setting the agregate genotype for all characteristics included in the programme (Groen et al, 1997). The agregate genotype in this case represents the genetic contribution or value of each animal in the realization of the goal. In order to set the agregate genotype for each characteristcs it is necessary to have certain parameters (genetic and phenotypic variances and co-variances) which are calculated from the base of the registered data previously measured and/or controlled traits.

For precise setting the agregate genotype it is necessary to correctly formulate the mathematicstatistical model which will contain the most important sources of non-genetic variability in order to precisely estimate the genetic component of the characteristics which are directly or indirectly included in the breeding programme. (Bogdanovic, 1999). This is extremely important because every change in the model, either through including or excluding the specific factor, directly impacts the rang of the breeding animals. (Bogdanovic et al, 1997). For including in the model it is necessary to chose those sources of variability which will contribute the most to the determination of the model, paying attention that each of these factors, separately considered, has an appropriate statistic value in the context of biological characteristics.

Knowing the value of the agregate genotype for the characteristics which are important for the realization of the set breeding goal, it is easier to create the breeding scheme and structure, i.e. it is possible to precisely determine the percentage of the animals which are being controlled, how the parent couples are being chosen and on which way will the improved characteristics spread within the population. Usually the genetic improvement is accomplished on the relatively small number of the heads of breeding stock, but on elite or nucleus heads, so on certain way their heriditary base spreads to the commercial farms as well. The reason for this is that the production can include even several hundred thousand animals, which due to high costs of the control and registration of the data neither can nor must all be involved in the control of the production capabilities.

What significantly differs the programme of the realization of the certain breeding goal comparing the general selection work in order to accomplish the genetic improvement for one characteristic or for a group of characteristics is an economic analysis of the accomplished activities which can not be avoided. Considering that, the breeding goal is the most often defined with the profit function which shows in which direction the change of the certain charactericts impacts on the increase of profit. The profit function is based on the bioeconomic model which included all biological certainties of the characteristics imporant for the breeding goal, as well as the quantity of the invested and earned capital. (Bogdanovic et al, 2004a).

The development of the breeding goals and programmes, as well as the setting of the necessary economic values must include the assessment of the future market conditions due to imporant chronological 
discrepancy between the time in which a certain selection activity is being realized and the time in which the expression of the selected genotypes is being registered. This is the reason why, for the realization of the breeding goals, are necessary the absolute as well as the relative economic values of the characteristics which are the subject of the selection work. The basic economic value included in the profit function must containt (1) the costs of nutrition, (2) the costs of work and equipment according to the time spent, (3) the value of the production and (4) the value of the animals (Harris and Newman, 1995).Very often, though, the breeding goal includes more than one characteristic, so that the economic value of a certain characteristic depends on the other characteristics included in the profit function. In that case, the economic value represents the partial regressive coeficient of the gained profit on the breeding value of each of the included characteristics. The economic value of the characteristics in the context of the breeding goals should be observed as a measurement up to which level the efficiency of the production will be improved in the moment of expression of one unit of the genetic superiority for the specific characteristics. (Groen et al., 1997).

When all previously mentioned steps are classified separately, the activities during the directed genetic improvement of one population of cattle should involve the following: (1) defining of the breeding goal, (2) setting the breeding programme, (3) setting the selection critieria, (4) creating the breeding scheme, (5) forming the breeding structure, (6) setting the plan for mating, (7) control of the descendants and (8) economic analysis of the programme (Garick, 2003, Bogdanovic et al, 2004a).

\section{Potential breeding goals and programmes in the cattle production in Serbia}

Generally speaking, in Serbia we have two cattle breeds which are dominant and which are raised in two production systems. Considering the dual purpose breeds the most common is the Simmental breed, as well as the domestic spotted cattle in the type of Simmental, while the most common amoung the specialized breeds are the Holstein and the European black-white breed. The other specialized breeds, no matter if we talk about the production of meat or milk, are negligable in numbers. The most common production systems in Serbia are the intensive and the semi-intensive system.

Considering the importance and the number of cattle, the most important are the breeding goals for the Simmental and Holstein-Friesian breed. Except these two breeds, lately there is a need for defining the breeding goals for small and relatively closed populations of the autochtonous breeds of cattle, as well as for the specific geographic areas which produce the local milk or beef products which fulfill the conditions for the protection of the geographic brand of origin (Bogdanovic et al, 2004b).

What is the situation with the breeding goals in cattle breeding in Serbia today? Until today the goals in cattle breeding, mainly, have been equaled with the desire to improve a certain quantitive characteristic. The improvement of the characteristics is a constant task of all those who are dealing with the refining the characteristics in cattle breeding, but this should not be the goal for itself. The improvement of the characteristics should be an instrument for realization of the set breeding goal. In the beginning it is necessary to define what must be accomplished by raising the Simmental or Holstein breed considering all their breeding differences and characteristics, but at the same time the present and the future breeding and market conditions in which the production will be organized. Also, we must not neglect the social aspects as well, because the production of milk and meat first of all must financially satisfy the breeder.

Having in mind that the Holstein-frisian breed and the Simmental breed are very different taking in consideration the purpose to which they belong, and also the way of phenotypic expression of some characteristics, it is necessary to define two different breeding goals. The goal for the Holstein-Friesian breed should be aimed into achieiving sufficient quantities of milk in coordination with the standards of the quality demanded by the European Union, while for the Simmental breed the general goal should be the optimal relation between the production of quality milk and meat emphasizing the production which brings more profit in the specific economic-breeding conditions. We must always bear in mind that in our production conditions the Simmental breed should provide both the production of milk and meat.

No matter what breed we consider, the general breeding goal for both breeds should be the accomplishing of such genetic improvement which will within the specific zootechnical and market conditions on the most efficient way use the available resources and contribute to the realization of the economic maintenance of the production. If we set these wide goals, we must include within the breeding programmes all those characteristics which directly or indirectly contribute to their realization. All these characteristics generally can be divided into three groups: (1) the characteristics important for the production 
of milk, (2) the characteristics imporant for the production of meat, and (3) the functional characteristics imporant for both productions.

The characteristics important for the milk production. For the production of milk the economically relevant traits will always be the quantity and the structure (the average milk production, the percentage of butter- fat and proteins). Besides these characteristics, the total number of somatic cells and the total number of microorganisms, as well, will be included in the system of quality evaluation, i.e. the premiums and penalties, and at the same time these characteristics will be included in the breeding programme. During the past decades, numerous domestic researchers have been dealing with the milk production matter in our conditions, but a few more researches have been done on black-white and Holstein breeds. The reason for this was, first of all, of organizational nature, because these breeds have been raised, and are raised still today on bigger, sometimes public, and today state and private farms on which it was possible to perform the controlled experiments. At the other side, the Simmental breed was mainly found in the private sector, which had, until not long time ago, a large number of small farms, although there were some public farms which were larger, but the majority unfortunately is closed today. Thou, amoung the breeders of the Simmental breed we can today separate the breeders who on their farms grow a larger number of heads of cattle, so from this aspect they are very interesting for the selection processes.

Out of the components which are necessary for defining the breeding programme for the milk production, today we are handling with the most important genetic and phenotypic characteristics of the certain traits. Thou, it is still necessary to define the relative importance of each of these traits included in the programme, as well as the agregate genotype for the certain traits which will show the contribution of the certain animals in the realization of the goal. In this sense, the programme can be realized on the national level, assuming that there is a clear and correct database which will enable this, as well as on the micro level, i.e. on the level of one association or even on the level of one larger farm. As one step forward comparing all other breeding programmes realized so far, it is necesary to do the economic analysis of the programme, as an assessment of the eficiency of the realization of the set goal. Without the economic aspect added, the achivement of the breeding goal is equaled with the list of the characteristics which are chosen for the selection without any specific results if the improvement of any characteristic is really profitable or not.

The characteristics important for the beef production. Comparing with the production of milk which had a dominant role in the selection processes, the production of beef meat in Serbia did not have such status. Instead it was developed as secondary production without any clear breeding direction. Still, we can not say that the beef production was developing absolutely without any selection work. This is especially seen in the fact that the young bulls in the performance test are tested first for the growth traits and body development, and then in the progeny testing they are tested for the milk and beef traits. Nevertheless, for planning of the improvement of the production of meat it is necessary to much clearly define the breeding goals with precise setting of the both economically relevant and indicator traits.

Beside the characteristics of growth and body development which have so far been the subject of the selection work, for the beef production are also important the maternal abilities, feed conversion, as well as the quantitive and the qualitative characteristics of the carcasses and meat. Since in the future the production of young beef meat in Serbia will mainly be organized by breeding the dual purpose cattle, the selection of the characteristics of meatiness should not cause the violation of the already achieved level of phenotipic expression of the milk traits, because in our production conditions the dual purpose cattle, first of all the Simmental breed, should provide the production of milk, and the production of meat as well (Bogdanovic et al., 2005).

The characteristics of the growth and body development represent the anatomic and physiologic base not only for the beef production, but for the production of milk as well. The researches done so far show that these characteristics possess enough variability for the successfull selection with the previously setting of the adequate model for the control of nongenetic sources of variation (Bogdanovic et al., 2003a, 2003b, Bogdanovic et al., 2002a, 2002b, 2002c, Bogdanovic, 2001a, 2001b). What is missing for defining the appropriate breeding programme is the mutual connection of the beef and meat traits of sons and daughter's milk production. Such combining of very different characteristics in one breeding programme influences that the selection work on the Simmental breed is much more complexed comparing with the specialized dairy breeds.

The possible way for the improvement of beef and carcass traits of the domestic Simmental breed is the systematic crossbreeding with beef breeds. So far the researches were done mainly on the French beef breeds, and earlier with the English as well. But, since the beef breeds do not have an important influence in Serbia, this procedure should be accepted in a more systematic way than it has been done until now, which 
means precisely defining what is really necessary to be achieved with the crossbreeding, with the detailed analysis of the part of the population which would be crossbreeded with the beef breeds and the choice of those breeds which would enable the realization of the set goals. The last mentioned is extremely important, because putting in favour one breed or a group of breeds comparing with the other breeds, by having an unsufficient number of information, potentially can have a bigger negative effect than the positive one.

The functional traits important for both productions. Out of functional traits which will either as economically relevant characteristics be directly included in the breeding goals or will represent the indicator characteristics which will be connected with the economically relevant characteristics, but are more convenient for the selection, the characteristics of type or conformation are important, some reproduction characteristics, milkability and temperament, the longevity, the health traitsetc. (Djedovic Radica, 2004, Djedovic Radica et al., 2004, Petrovic M.D., 2004a, 2004b, 2003).The trends today in the modern milk and beef production do not accept at all the single selection only for economically relevant production characteristics, because this can highly contribute to the numerous metabolic disorders and shortening of the production life (Groen et al., 1997). The modern breeding goals and programmes in the cattle breeding are mostly aimed at achieving and maintenance of the optimum balanse between the production and functional characteristics without disturbing the health or welfare of animals. We can conclude for all these characteristics that they represent the aiming group of characteristics which should be emphasized in the future researches of the cattle breeding, so they could be adequately included in the breeding programmes.

At the end we should point out that on defining the future breeding goals in the cattle production, and in the livestock production in general, a big impact can have the Strategy of development of agriculture in the Republic of Serbia. Also, an important impact on the breeding goals in the cattle breeding should have the breeder's associations (mainly the breeder's associations of the Simmental breed), the large dairy plants and slaughterhouses as well. Dairy plants, especially the large once, can potentially have a very big impact on the breeding goals by directing the producers in the very defined direction having in mind the initiative of the competent ministry which for its goal has the improvement of the quality of milk and the achievement of the European standards in this area until the year 2010 at the latest.

\title{
ODGAJIVAČKI CILJEVI I PROGRAMI U GOVEDARSTVU SRBIJE
}

\author{
V. Bogdanović, Radica Đedović, P. Perišić, M. M. Petrović
}

$$
\text { Rezime }
$$

Da bi govedarstvo, kao najvažnija grana stočarske proizvodnje, bilo ekonomski isplativo, neophodno je da postoje jasno definisani odgajivački ciljevi koji se žele postići, kao i programi kako će se oni realizovati. U Srbiji mogu da se identifikuju dve najvažnije grupe rasa goveda koje se međusobno razlikuju po brojnim fenotipskim i proizvodnim osobinama. To su holštajn-frizijska rasa i evropska crno-bela goveda na jednoj strani i simentalska rasa i domaće šareno goveče u tipu simentalca na drugoj strani. U poslednje vreme značaj ponovo dobijaju buša i podolsko goveče, ali sa aspekta očuvanja geno-fonda u okviru nacionalnog programa zaštite i očuvanja animalnih genetskih resursa. U radu su prikazani osnovni principi definisanja odgajivačkih ciljeva u govedarstvu, kao i načini za određivanje odgajivačkog programa i selekcijskih kriterijuma, kreiranje odgajivačke šeme i strukture, izbor roditeljskih parova i utvrđivanje plana parenja, kontrolu proizvodnih sposobnosti i ekonomsku analizu realizovanih aktivnosti.

Ključne reči: Goveda, odgajivački ciljevi, odgajivački programi, modeli, varijabilnost osobina, ekonomska vrednost osobina.

\section{Literature}

1. BOGDANOVIĆ, V., ĐEDOVIĆ RADICA, PETROVIĆ, M.M. (2005). Mogućnosti za selekciju simentalske rase goveda na osobine tovnosti i mesnatosti u srbiji. Biotehnologija u stočarstvu, 21 (3-4) (prihvaćen rad za štampu). 
2. BOGDANOVIĆ V., ĐEDOVIĆ RADICA, PERIŠIĆ P., PETROVIĆ M.M. (2004a). Principi definisanja odgajivačkih ciljeva u stočarstvu. XVI Inovacije u stočarstvu, Biotehnologija u stočarstvu, 20 (5-6), 61-68.

3. BOGDANOVIĆ V., PETROVIĆ M.M., DUŠICA OSTOJIĆ (2004b). Zootehnički uslovi proizvodnje od značaja za geografsku oznaku porekla autohtonog sjeničkog sira. Biotehnologija u stočarstvu, 20 (1-2), 23-27.

4. BOGDANOVIĆ, V., PETROVIĆ, M., ĐEDOVIĆ, RADICA, PERIŠIĆ, P. (2003a). Faktori koji utiču na varijabilnost proizvodnih osobina bikova različitih rasa u performans testu. 7. Međunarodni simpozijum o stočarstvu, Biotehnlogija u stočarstvu, 19 (5-6), 65-71

5. BOGDANOVIĆ, V., ĐEDOVIĆ, RADICA, POPOVIĆ, Z., PETROVIĆ, M. (2003b). Uticaj različitih faktora na varijabilnost dnevnih prirasta bikova u testu. Simpozijum "Naučna dostignuća u stočarstvu i konkurentnost poljoprivrede", Herceg Novi, 16-20. jun, Savremena poljoprivreda, 52 (3-4).

6. BOGDANOVIĆ, V., POPOVIĆ, Z., VIDIĆ-ĐEDOVIĆ, RADICA, (2002a). Komponente varijansi osobina porasta simentalskih bikova u performans testu. XV Inovacije u stočarstvu, 14-15.11.2002., Beograd. Biotehnologija u stočarstvu, 18 (5-6), 23-30.

7. BOGDANOVIC, V., DJURDJEVIC, R., PETROVIC, M. (2002b). Changes in components of variance of growth traits during the performance test of Simmental bulls. 7th World Congress on Genetics Applied in Livestock Production, 19-23 August, 2002, Montpellier, France. Proceedings, 846.

8. BOGDANOVIĆ, V., ĐURĐEVIĆ, R., POPOVIĆ, Z. (2002c). Fenotipska varijabilnost i naslednost osobina telesne razvijenosti kod performans testiranih simentalskih bikova. Savetovanje "Stočarstvo i agroekonomija u procesima tranzincije", Novi Sad - Hercesg Novi, jun 2002. Savremena poljoprivreda, $51(3-4), 89-91$.

9. BOGDANOVIĆ, V. (2001a). Performans test simentalskih bikova u Srbiji: (I) Fenotipska varijabilnost osobina porasta. Arhiv za poljoprivredne nauke, 62 (216-217), 93-104.

10. BOGDANOVIĆ, V. (2001b). Performans test simentalskih bikova u Srbiji: (II) Fenotipska varijabilnost osobina telesne razvijenosti. Arhiv za poljoprivredne nauke, 62 (218-219), 15-25.

11. BOGDANOVIĆ V. (1999). Izvori varijabilnosti za proizvodne osobine bikova tovnih rasa. Arhiv za poljoprivredne nauke, 60: $210(1-2), 101-118$.

12. BOGDANOVIĆ V., CONTIERO BARBARA, MANTOVANI R., BITTANTE G. (1997). Uticaj modela na rangiranje priplodnjaka. Biotehnologija u stočarstvu, 13 (5-6), 267-272.

13. DEKKERS J.C.M., GIBSON J.P. (1998). Applying breeding objectives to dairy cattle improvement. Journal of Dairy Science, 81 (2), 19-35.

14. ĐEDOVIĆ RADICA, LATINOVIĆ, D., BOGDANOVIĆ, V., TRIFUNOVIĆ, G. BESKOROVAJNI RADMILA (2004). Naslednost osobina plodnosti u progenom testu bikova holštajn-frizijske rase. XVI Inovacije u stočarstvu, Biotehnologija u stočarstvu, 20 (5-6), 41-46.

15. ĐEDOVIĆ RADICA (2004). Ocena tipa teljenja i učestalost genetskih anomalija u testu po potomstvu holštajn-frizijske rase. Doktorska disertacija, Institut za stočarstvo, Poljoprivredni fakultet, Beograd.

16. GARICK D. (2003). Personal communication.

17. GROEN A.F. (2000). Breeding goal definition. In "Developing breeding strategies for lower input animal production environments", Eds. S. Galal, J. Boyazoglu and K. Hammond. ICAR Technical Series, No. 3, 25-104.

18. GROEN A.F., STEINE T., COLLEAU J.J., PEDERSEN J., PRIBYL J., REINSCH N. (1997). Economic values in dairy cattle breeding, with special references to functional traits. Report of an EAAP-working group. Livestock Production Science, 49, 1-21

19. HARRIS D.L., NEWMAN S. (1994). Breeding for profit: synergism between genetic improvement and livestock production (A review). Journal of Animal Science, 72: 2178-2200.

20. OLESEN I., GJERDE B., GROEN Ab F. (1999). Methodology for deriving non-market trait values in animal breeding goals for sustainable production systems. Proceedings "Genetic Improvement of Functional Traits in Cattle: Breeding Goals and Selectioin Schemes", GIFT Workshop, 31-40, Wageningen.

21. OLESEN I., GJERDE B., GROEN Ab F. (2000). Definition of animal breeding goals for sustainable production systems. Journal of Animal Science, 78: 570-582 
22. PETROVIĆ, M.D., SKALICKI, Z., BOGDANOVIĆ, V., BOGOSAVLJEVIĆ-BOŠKOVIĆ SNEŽANA (2004a). Uticaj paragenetskih faktora na osobine životne proizvodnje kod krava simentalske rase. XVI Inovacije u stočarstvu, Biotehnologija u stočarstvu, 20 (5-6), 95-100.

23. PETROVIĆ, M.D., SKALICKI, Z., GUTIĆ, M., BOGDANOVIĆ, V. (2004b). Uticaj paragenetskih faktora na osobine dugovečnosti krava simentalske rase. Biotehnlogija u stočarstvu, 20 (3-4), 23-29.

24. PETROVIĆ, M.D., GUTIĆ, M., SKALICKI, Z., BOGDANOVIC, V. (2003). The effect of age at first insemination on longevity and lifetime production traits in Simmental cows. Acta Agriculturae Serbica, 8 (15), 57-61.

25. WERF van der J. (2002). An overview of animal breeding programs. In "Animal Breeding: Use of New Technologies", 2-9, Purdue University Press. 